\title{
sciendo
}

\section{TRANSFORMING NEWS JOURNALISM FROM NEWSPAPERS INTO ONLINE MEDIA OUTLETS IN KOSOVO}

\author{
Faton Ismajli
}

\begin{abstract}
The development trend of online journalism in Kosovo continues with great strides in relation to newspaper journalism. Some newspapers are continuing to survive and still on market despite the decline of readers as part of a worldwide trend of readers moving to online platforms. This study will analyze the content of journalistic texts in newspapers and online media, measuring their core values. This study is about the transformation, namely the change of journalism standards from traditional media (newspapers) to online media. Journalism theorists argue that the standards of journalism should be the same in newspapers and online media. But the practice in Kosovo is completely different. The main hypothesis of this study is that professional standards in online journalism in Kosovo have fallen; in newspaper journalism, however, there is still a high level of professionalism in writing and reporting. To test these two hypotheses, texts from two newspapers and two online media shall be analyzed. Therefore, the analysis will be done on texts from "Zëri" and "Koha Ditore" newspapers, and their online versions, "zëri.info" and "koha.net".
\end{abstract}

Key words: Kosovo, online journalism, text, standards, transformation, "Zëri", "Koha Ditore"

\section{Introduction}

This study discusses the development and evolution of online journalism in the two main media in Kosovo, koha.net, and zëri.info. The measurements in these two media have been made in newspaper texts as they have the same version of the 'Koha Ditore' and 'Zëri' and the online media. 60 texts were analyzed for each media making a total of 240 news journalism texts. It provides a thorough analysis of professional standards in journalism. Based on the research findings, conclusions are drawn.

Research Question: How has information journalism been transformed in Kosovo in the age of online media?

As elsewhere, Kosovo has also witnessed a major technological development that has affected the media and has led some of them to discontinue print versions and remain only online. In this form, journalism has changed both substantially and structurally. So we are changing the way we report and write the news. Consequently, the change of standards is also taking place. It will be tested in this study whether they have 
changed for the better or whether they have been degraded.

The first hypothesis: Journalism from newspapers to online media is distorted as a result of technology.

In this study, we focus much more on the internal (text) aspect and not on the external (social circumstances) of text writing. Distortion of journalistic standards is measured by conducting a substantive and structural analysis of texts to arrive at a result based on research findings. This measurement is done by analyzing the content and analyzing how the news is written.

The second hypothesis: The information genre has changed substantially both in structure and content.

The construction of the journalistic text has changed from the title to the rest of the text. One is the fact that the news is fast, it is also directly reported, and, secondly, it has changed in content.

The study aims to highlight how journalists use technology and the internet to report and write in online media, specifically at koha.net and zeri.info, as the two largest online media with the highest life expectancy and impact on the media life of Kosovo due to the fact that printed versions of newspapers still exist and they are still published. This study will benefit journalists, students, but also media owners and those interested in the latest developments in journalism, through concrete results showing the trends of this journalism in Kosovo.

From the academic point of view, the study aims to show - through the results and concrete content analysis - how the media report and write news by making comparisons between print and online media. This study serves as the launch of new media studies in Kosovo and explores other aspects of this area of media including ownership and media management.

The results of this study reveal some disturbing data on the lack of technological opportunities provided by the internet, which makes online journalism incomplete, leading to content gaps in online media. Even in Kosovo, as in most of the world, newspaper journalism has been stabilized and standards of journalism have been established, but online journalism is still in the transition phase and the results of this study can be used not only by the media that are part of the study, but also by other media in Kosovo and around the world to further embrace technology and take advantage of the internet's advantages over the newspaper, which comes out once every 24 hours, while online journalism is published at any time. Furthermore, in Kosovo, based on measurements of the Internet World Status, more than 80 percent of the population of more than 1.9 million have access to the internet. There are more than 910,000 Facebook accounts as well.

\section{Media Context, Koha and Zëri}

Koha Ditore and Zëri newspapers have been selected because of their importance in the Kosovo media market, because of their tradition of being among the first newspapers in Kosovo and because they are almost the only ones to publish a print version besides operating as online media.

The Kosovo Encyclopedic Dictionary (Fjalori Enciklopedik i Kosovës) states that Koha Ditore is Kosovo's independent daily and started as a newspaper, initially publishing the weekly newspaper Koha, which was kicked off in1990. Meanwhile, the first issue of Koha Ditore was released on March 31, 1997, while "Koha Javore" continued to be published for a while. From March 10, 1998, 'Koha Ditore' has been published daily. The founder is Veton Surroi, while the current director is Flaka Surroi.

"During the war (1998-1999) the newspaper was noted as the most cited source of news from Kosovo in the international media, and due to its reporting on Serbian crimes in Kosovo, Koha Ditore also had a diaspora edition, informing Albanians in Western Eu- 
ropean countries, and in January and February 1999, at the time of the negotiations on Kosovo in Rambouillet and then in Paris, the newspaper also published the English language edition "KD Times". On the night of the NATO bombing on March 24, 1999, newspaper offices were attacked by Serbian police, the newspaper guard was killed and the printing press burnt down" (Fjalori Enciklopedik i Kosovës 2018, p. 492).

The online media, Koha.net, was first registered on the internet in 1997 (who.is, n.d.), but that it did not function as an online media until after 2010. 'Koha.net' was also in operation for some time during the war in Kosovo in 1999. This is evidenced by texts that are still stored online on the reports of that time (web.archive.org, n.d.).

According to the Fjalori Enciklopedik i Kosovës (Encyclopedic Dictionary of Kosovo), the newspaper "Zëri" started publishing in early 2000, succeeding the weekly magazine "Zëri", or "Zëri i rinisë" published earlier in Prishtina. "At the end of 1999, they published the first issue of this daily newspaper, with director Blerim Shala and editor-in-chief Bardh Hamza. They created the newspaper's informative, political and cultural profiles, launching a newspaper that was quickly profiled in the Kosovo media market" (Fjalori Enciklopedik i Kosovës , 2018, p. 492).

The online newspaper, Zëri.info, based on the web.archive website, acquired the domain in 2006 as it began publishing news in 2011. For the first time in Kosovo, the internet was used in 1994 in Pristina while texts that are still on the internet date 16 January 1998, published by kosova.com news agency (web.archive.org, n.d.).

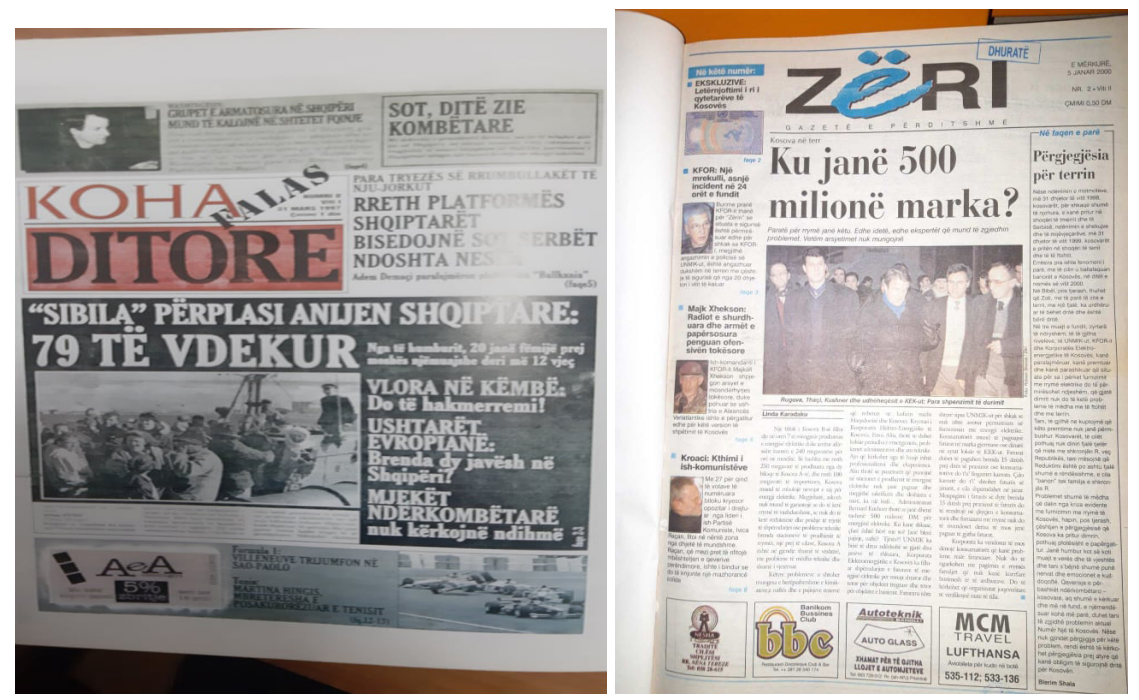

Figure 1: Front pages of two newspapers in the first published issues. Source: National Library of Kosovo

\section{Theoretical Background}

In Kosovo there have been no in-depth studies of the changes that have taken place and how online journalism has been transformed in relation to newspapers. However, other studies around the world show that in some developed countries online journalism is standardized and higher professional standards have been applied, using technology. Media studies professor Mark Deuze at the University of Amsterdam and co-author Tamara Witschge, in their research paper entitled "Beyond journalism: Theorizing the transformation of journalist", use the concept "beyond journalism" for the fact that journalism is changing and it is dynamic. According to them, the news industry is unsustainable both structurally and socially in the audience. These authors argue that journalists should go beyond the boundaries set earlier because they are more productive. "Beyond journalism is, as we have hoped to have shown in this article, not a new conceptualization of the field - it is also not simply advocating scholars and students alike to denounce existing definitions of what we understand news work to be. Rather, it has argued 
that going beyond boundaries is what is productive in this time of flux. In recognizing this theoretical point, we would in fact ground our work more solidly in the lived experience of journalists and doing journalism" (Deuze \& Witschge, 2018, p.177).

However, in this study, Kosovar journalists do not go beyond the boundaries. In fact, they do not extend the possibilities that lie within the boundaries allowed by the internet and technology. Steve Paulussen, of the University of Antwerp, in his study "Technology and the Transformation of News Work: Are Labor Conditions in (Online) Journalism Changing?" finds that technology has had implications for the work of journalists, the quality of news, the accuracy of news, and the professionalism of journalists. "Therefore, it is important to keep monitoring evolutions in employment and labor organization in the news industry, especially given that most of the trends are likely to deteriorate rather than improve. At the same time, it is also important to reflect on how journalists can empower themselves to cope with the changes, uncertainties, and demands of contemporary news work" (Paulussen, 2012, p. 205).

The journalism conducted in the newspapers had set some rules that had been established. Meanwhile, online journalism is still evolving and transforming. Despite all the difficulties, online media are adapting to the professional rules that were applied to newspapers. Technological development has also shifted the foundations of journalism and the role of the journalist from a text writer to a person who has many functions in online media. In online media, in addition to writing text, the journalist also serves as editor, photographer, cameraman, proof-reader and technical worker. However, journalism standards have not changed, at least theoretically, for news writing.

Stefan Russ-Mohl, a journalism professor, writes that in the online media, everything is written but not all that is offered is journalism and much less good journalism. According to him, all the rules that apply to traditional journalism also apply to online journalism. Melvin Mencher believes that if standards fall, it will also cause online journalism to lose value in relation to the value that traditional journalism has had. As for others, for serious web providers, the same rules and standards apply as to traditional journalism. Unchecked network quality standards can act as a boomerang on the parent newspaper (Russ-Mohl, 2010, p.184).

However, the rules of writing journalistic texts in some journalistic texts do not apply to online journalism as the author, in most cases, thinks more about publishing the news faster than the quality of the text. This has prompted discussions and raised questions about the rules of text writing.

Kosovar Professor of journalism Bajram Kosumi, in his two books on journalism genres, highlights the changes that have occurred in the writing of news in newspapers and online media. According to him, the news has a well-organized and precise textual structure that is very unique and linear. Some fixed forms of journalistic text have been created, e.g. different is the news for the daily newspaper than the news for the newspaper or the weekly magazine, and quite different for the television and digital portal (Kosumi, 2013).

Kosumi writes that the structure of news published at the beginning of the 20th century was very different from the structure of news published at the end of the 20th century.

Earlier the journalistic text, especially in journalism in totalitarian societies, followed the principle of writing texts following the chronological order. Newspaper writing is based on the most important information. Whereas, in the internet media, the news is written combining these two factors. If reported live, the temporal aspect of chronological writing will be followed and then the principle of writing the most important information in the lead will be followed.

Two Albanian journalism scholars, Hamit Boriqi and Sami Nezaj, see journalism standards as natural in online newspapers as they are a continuity of newspapers. Initial- 
ly, it appeared as a copy of the content of newspapers or television and then developed as a form of separate journalism (Boriçi \& Nezaj, 2017, p.174).

Online journalism in Kosovo has developed since 1999 and mostly after 2010 when part of the media went online and some of them even continued their print editions. Two online media that were in operation at that time are the Kosova Center Information (in Albanian, Qendra për Informim e Kosovës, QIK) and koha.net, which reported on the events of that time. Published texts are still on the internet, in the web archive, where the activity of those two online media is saved. These two media have reported in two languages, English and Albanian (web.archive.org, n.d.).

The speed with which the information is cracked has brought back the goal of causing a sensation, and with it, a more vulgar writing style.

A journalism professor at the University of Prishtina, Milazim Krasniqi, lists four problems of the new media in relation to the profession of journalism. The first, according to him, today's journalism, in the race against time to report in real-time, is becoming speculative and even deceptive, being many times unfaithful to its sources and ethics. The second problem is that today's journalism has to do with its implication with espionage as was the case with Wikileaks. The third problem of journalism is the change of course of the journalists who produce top journalism. "The fourth current problem, related to genuine journalism, is the powerful impact of social media on the public, starting an eclipse process of classical journalism" (Krasniqi, 2014, p.11).

However, the biggest problem with the structure of texts in online journalism is the lack of explanation of the circumstances that led to the event. Very little news can be complete without some background information. Reporters who ignore this advice act at the risk of informing readers and listeners inaccurately. Events have causes and consequences (Boriçi \& Nezaj, 2017, p.103).

Brian S. Brooks, George Kennedy, Darl R. Moen and Don Ranly of the Missouri Group give importance to the textual structure and writing of the news. Of course, writing online is not just about writing. It is also about determining the best way to report on an event and then using all forms of media - text, audio, video, and graphics - to convey it. This requires at least a basic understanding of audio output and the use of informational graphics. However, writing is at the heart of all media, including the web (Missouri Group, 2005, p.374). According to them, online media readers want links, graphics, audio, and even video to accompany the text.

All of these online journalism requirements bring the need of a greater engagement of journalists and require young professionals who, in addition to journalistic work, know how to do the job of editor, proof-reader/language editor, photographer, and technical officer posting news on the online media.

Eric Scherer, a French Professor, sees the need to transform journalism because of technological developments. Consequently, even the forms of its writing. It is not the time to invent, but to transform. It is no longer 'adapt or die' but 'change or die'. Because while traditional media shrinks in the face of digital, the public and advertisers, often tech-savvy will simply look elsewhere (Scherer, 2012, p.36). Of course, technological changes are also demanding that the journalist be transformed and adapted to reality so that journalism is also subject to new rules of writing and use.

Scherer believes that the digital revolution and the internet have changed everything; the audience has taken control of the means of production and distribution of traditional media. Major journalist missions are divided even threatened. Traditional media are in crisis. The new media are now under the power of three forces: digitalization, mobility, and personalization. Three forces that blur the boundaries between professional life and the private sphere (Scherer, 2012, p.39). Scherer also sees the problem in the old media, and because of non-transformation, it has been side-lined by the public, politicians, big companies, athletes and actors (Scherer, 2012, p.42). According to him, the internet 
has changed our ways of reading and diminished our attention span; it entices us to consume more information and to subject ourselves to many ideas, to the detriment of perhaps in-depth analysis. However, in addition to the audience's demand, journalists are required to maintain journalistic standards so that the value of this profession does not fade, but increases even more with the credibility of the audience.

The authors of the Missouri Group recommend that the best way to save people time is when journalists are clear in their writing. Choose the simple word; vary the length of the sentences, but keep them short. Write a short paragraph. Help readers. This book explains that earlier journalists were not worried about how their articles would be published until they explained to internet journalists that they were much more cautious. In short, if you are writing for online media, you have to be much more than a writer. You must have other skills as well. Online journalism requires a great deal of cooperation and not just with other journalists. Working closely with those more expert than you at graphic design and photography becomes essential at first (Missouri Group, 2005, p.380). The Missouri Group writes that online journalists have far less room to be ironic and literary. They are expected to be precise and clear.

The news in both old and new media should contain some professional and ethical standards, no matter where it is published. To be good news, it must contain a headline containing the key information, a well-written and understandable headline, and a supporting material, a background showing the circumstances why the event happened and, if possible, then also support it with background material. Likewise, a news item must consist of at least two or more sources, so that the news is balanced and does not have only one source. Accuracy is also another professional element in writing news. Readers online typically want to read only as much as they have to; layering allows them to read as much or as little as they want. These information layers can include:

- Headlines (or titles), subheads and sub-subheads

- One-sentence teasers and lead-ins

- Brief summary paragraphs

- Visuals, photos, graphics

- Audio or video clips

- Related stories

- Related links (Carroll, 2010, p.32).

\section{Methodology}

The texts for analysis are selected within an artificial week. Three texts were taken for each day of the week, one in the morning, one at noon and one in the evening. A criterion for the evaluation of texts was followed based on the importance of the topics covered, the manner of writing journalistic texts. Literature in this field will be consulted, including authors Melvin Mencher, David Randall, Bajram Kosumi, the Missouri Group book, and others.

The analysis of this study is based on 240 texts, 80 of the Koha.net, 80 of the Zëri. info, 80 of the Koha Ditore newspaper and 80 of the Zëri newspaper. The text collection period is from February 14 to April 4, 2017. The texts were compiled using the "Artificial Week" method and only informative journalism texts were selected. The first text published on the portal in the morning is selected, then the first text published after 12 noon and the last text published that day. Different days have been selected so that all days of the week are part of the study. They have also been selected from three texts per day at different times to distribute the timing of news coverage on online media as much as possible. An "artificial week" of text selection is used also for newspapers, from February 15 to April 3,2017 . The text selection is made by taking a text on the first, third and fifth pages. Texts on pages one, three and five were selected because they are the most 
important and representative texts of the newspaper. As in the online media, the whole week's selection is made to avoid giving one day more importance than the next.

Sampling "Artificial Week" or otherwise known as "Constructed Week" is a type of stratified sampling method. This technique involves media content based on the day and week. Studies have shown that weekly built-in sampling can reduce the possibility of overestimating or underestimating certain days of the week (Hwalbin Kim et al., 2018).

This study deals with the change of journalism based on content analysis of text in two forms of media, written and electronic. The advantage of the study is that it shows the trend of online journalism's development in Kosovo, in a country where people's access to the internet is high, as around 90 percent of citizens have access to the internet and are able to read news.

The disadvantage of the study is that all the change in journalism, derived from this research, is based on the textual analysis, but not on the social context analysis of the journalist. This study does not analyze why journalists do not take advantage of opportunities provided by the internet to improve the quality of online journalism, including the possibilities of using photos, videos, graphics, hyperlinks and audio. To find out the causes outside the text, a new research should be conducted by interviewing journalists and building a questionnaire to determine whether lack of education is affecting journalists to build higher standards in online journalism, whether social background is affecting not to have quality journalism or whether media owners have minimal requirements in relation to journalists and the latter fit what the employer requires. All of these dilemmas can be answered by conducting a new research.

\section{The analysis of genre transformation}

\section{Lead}

Journalist scholar David Randall quotes American writer Paul O'Neill in his book The universal journalist, who says that a lead is like someone grab the reader by the throat in the first paragraph, sink their thumbs into his windpipe in the second, and hold them against the wall until the tag line. So the function of the lead is to put the reader inside the text. A well-written lead increases the chances that the reader will read the rest of the text and understand the reported event. Journalists are required to invest heavily in lead writing. Randall writes that the good lead is intended to arouse the interest of readers, to be simple and unambiguous.

Melwin Mencher writes about the delayed lead and the missing lead, buried or lost, finding that one way of writing damages the purpose of the news. The most common mistake of beginners is to bury the lead, to hide it in the multitude of words in the story (Mencher, 1998, p.129).

The analyzed texts on online media are written in most cases with a direct introduction. Of the 80 texts analyzed at koha.net, it appears that more than half of them, or 56 texts have a direct lead, 13 have a late lead, while 11 texts have a missing lead. The missing lead includes the texts that provided the news in the last part of the text and the content of the news was not properly identified. 


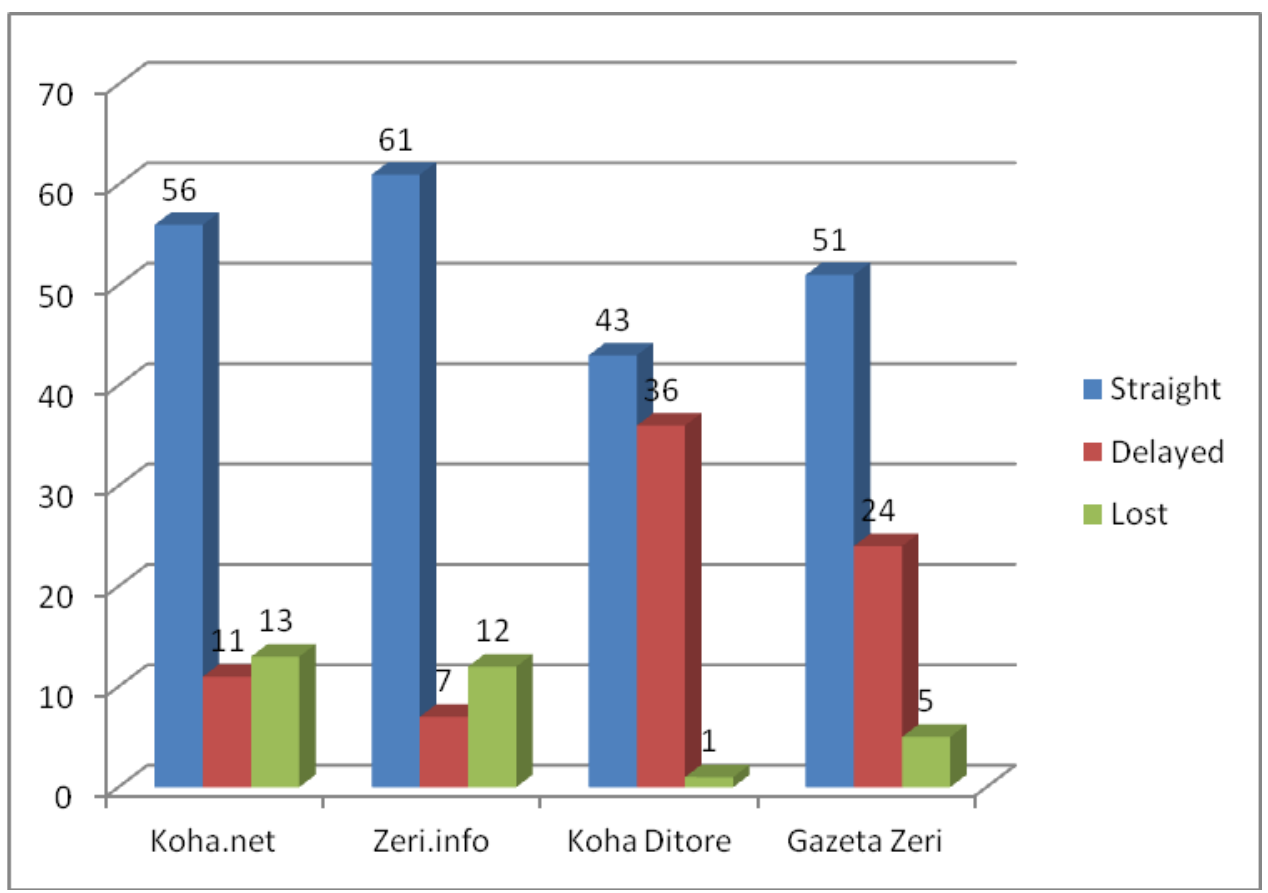

Table 1. The type of lead in both newspapers and online media.

Source: own processing, 2019

At zëri.info, out of 80 analyzed texts, it appears that 61 texts have a direct lead, 7 were with delayed lead, while 12 with missing lead. In contrast to online media, from 80 texts of Koha Ditore newspaper, it appears that direct lead is less used in newspaper than in online media. 43 news texts have a direct lead, 36 texts have a delayed lead, while only one text has a missing lead. The Zëri newspaper also has a larger number of texts with a direct lead. Only 24 have a delayed lead and 5 texts have a missing lead.

\section{The straight lead}

The straight lead is the lead that is widely used in the construction of the journalistic text. Firstly, because it is easier to write and secondly because it gives the key information and makes it clear to the reader from the first sentence what the key information is.

In the text entitled "The US wants KSF transformation through the Constitution", the text is written in the direct lead. There is information that a Kosovo initiative is being undertaken to establish the Kosovo army without international permission. And then, it also shows the attitude of the internationals that the establishment of the army needs to go through constitutional changes.

President Hashim Thaçi announced on Monday the initiative to advance the Security Force (KSF) in the military without the blessing of international factors, such as NATO and the United States of America. The internationals want the military to be made through constitutional changes (Koha.net, 7 March 2017).

This type of lead is obvious because it tells the story and gives the news from the first sentence. The lead is answering the questions Who? Where? What? How? Why?

In the text of the zeri.info, entitled "Hoxha: The Dehari case ends when the family demands an independent inquiry", the direct lead has been used. It reports that Astrit Dehari's family has selected a Swiss clinic to carry out a new expertise on the "Dehari Case".

In March of this year, the family of Astrit Dehari submitted a request to the Ministry of Justice to select the University of Lausanne, Switzerland, to conduct an independent investigation into the death of Astrit Dehari. Investigations, in this case, will only be completed after the Dehari family requests an independent investigation (Zëri.info, 2 April 
2017).

Such a lead enables the reader to understand from the outset the essence of the news, which is also the main function of the journalistic text, whether in online media or in a newspaper.

The main text of the March 22 newspaper 'Zëri' titled "Race for Prishtina increases dissatisfaction within parties" (Hoxha, 2017, p.3) is written with a direct lead. It says that Shpend Ahmeti and Lirak Çelaj are the two candidates who will enter the race for local elections in Prishtina; the other parties have not yet announced the names of their candidates.

Koha Ditore report dated March 22, 2017, tells how Serbia is seeking voting and counting in Kosovo and the title of the text is: "Serbia seeks voting and vote-counting in Kosovo".

Lead: Official Belgrade is insisting on holding the presidential elections in a uniform manner, including Kosovo within its electoral map (Neziri, 2017, p.3).

It writes a straight lead indicating how Belgrade has an intent on installing the same way of presidential elections also in Kosovo. It provides key information. The main event information is provided and elaborated by providing additional information in the rest of the text. The lead relates to the headline - making the topic and its continuation clear to the reader by following the most important elements of the news.

One form of lead, not the most appropriate one, is the lost lead, when the news is delivered neither in the first paragraph nor in the second. Usually, in such writing forms, the lead is written in the last part of the text.

The news, dated February 14, titled "Hoxhaj meets British MPs, secures British support", has a delayed lead, as it is first reported that the Deputy Prime Minister has met with MPs in the UK Parliament; then information is given on the conversations they have had about interstate relations.

Lead: Minister of Foreign Affairs of Kosovo, Enver Hoxhaj, received in a meeting a group of Members of the Parliament of the United Kingdom, with whom he discussed the interstate relations and cooperation between the two countries.

The last sentence of the text provides the most important information on British support for Kosovo as presented in the title. This type of heading is not effective because it does not tell the main story and consequently does not even engage the reader with the text.

\section{Background}

\section{Text without background}

As for the background on the texts analyzed in the online media, most of the texts have no context at all. Texts are written without explaining why that event happened. The connection of that event to other events is not indicated. Consequently, the texts do not provide sufficient explanations for the reported event.

Journalist researcher Mencher urges journalists to always use a background in texts because not using background always risks jeopardizing readers' accurate information (Mencher, 1998, p.295).

However, in the practice of the two media analyzed, it turns out that the background is not used in the texts of the online media. Thus, out of 80 texts analyzed at koha.net, it turns out that only 11 news have backgrounds. There is a similar situation when it comes to zeri.info. Of the 80 texts, only 9 have backgrounds.

Another situation is in the newspapers. In 'Koha Ditore', there are 79 texts that have a background while only one does not. 'Zëri' newspaper has 71 of 80 texts with a background. So, most newspaper texts have a background that explains the story while texts 
in online media do not have any background.

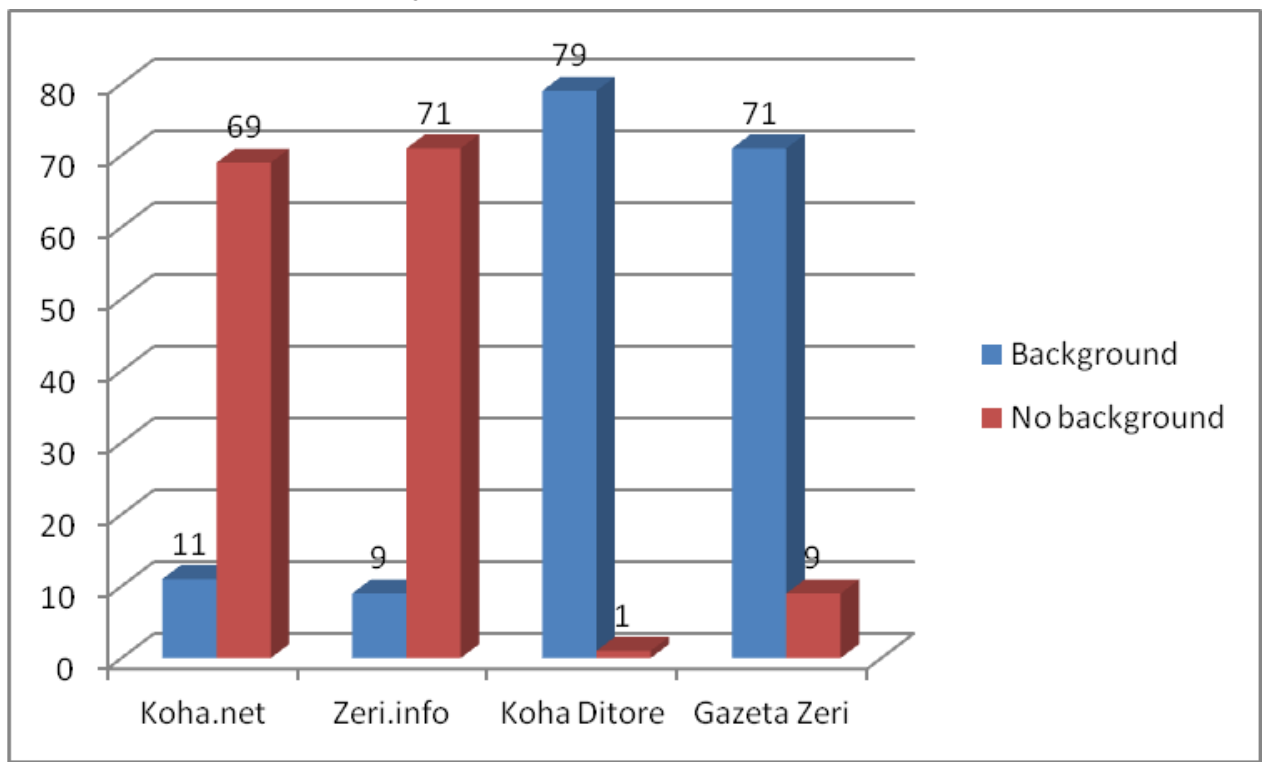

Table 2. The use of backgrounds in texts.

Source: own processing, 2019

The news item published on koha.net entitled "Topalli says that veterans have realized that those who are to be tried in the Special Court are victims" (Koha.net, 03 March 2017), has no background. It speaks of a statement given by an MP about the participation of veterans in sessions of the Assembly of Kosovo. The second sentence goes to a completely different topic, which is about who will be tried by the Special Court. Neither the Special Court nor the persons to be tried by this court have any necessary explanations. Then, it goes on with a statement directly quoting the MP: "PDK and LDK are guilty of establishing the Special Court". This quote is also incomprehensible because it does not explain why the two parties are guilty of establishing the Special Court.

Texts that have no background are not understood as they do not provide the explanations needed to tell the story.

Even in the zëri.info, the text entitled "Djuric says Serbia has serious evidence for Haradinaj case" (Zëri.info, 12 March 2017) is not given a background and the news story is not understood. It writes about a reaction by a Serbian official on the arrest of Ramush Haradinaj. But nowhere is it clear why he was arrested and when he was arrested. No details are given regarding the event for which most media outlets wrote.

Sometimes online media do not pay attention to texts to set the background even for the fact that there is a lot of reporting on an event, creating the idea that there is no need for additional explanations through the background.

\section{Sources}

The analysis of texts in two newspapers and online media shows that most of the texts with one source are published in online media. In the texts analyzed at koha.net, there are 46 one-source texts, 31 two-source texts, while there are also texts without any source.

Sources in journalism are important because they give credibility to the text. When a text is not sourced then it risks credibility and avoids professional reporting rules.

At zëri.info, there are 55 single-source texts while 13 are with two or more sources. Unlike koha.net, in the other online media, zëri.info, there are more non-source texts, in total 12.

The situation is better in the newspapers. Of the 80 texts analyzed in Koha Ditore, it turns out that most texts or 74 have more than two sources. Only 4 texts are with 
one source while two texts have no source at all. At Zëri the situation is close to that of Koha Ditore. From 80 of the analyzed texts, it appears that 68 texts have more than two sources and 8 have one source. Only 4 texts have no source and are published without any reference.

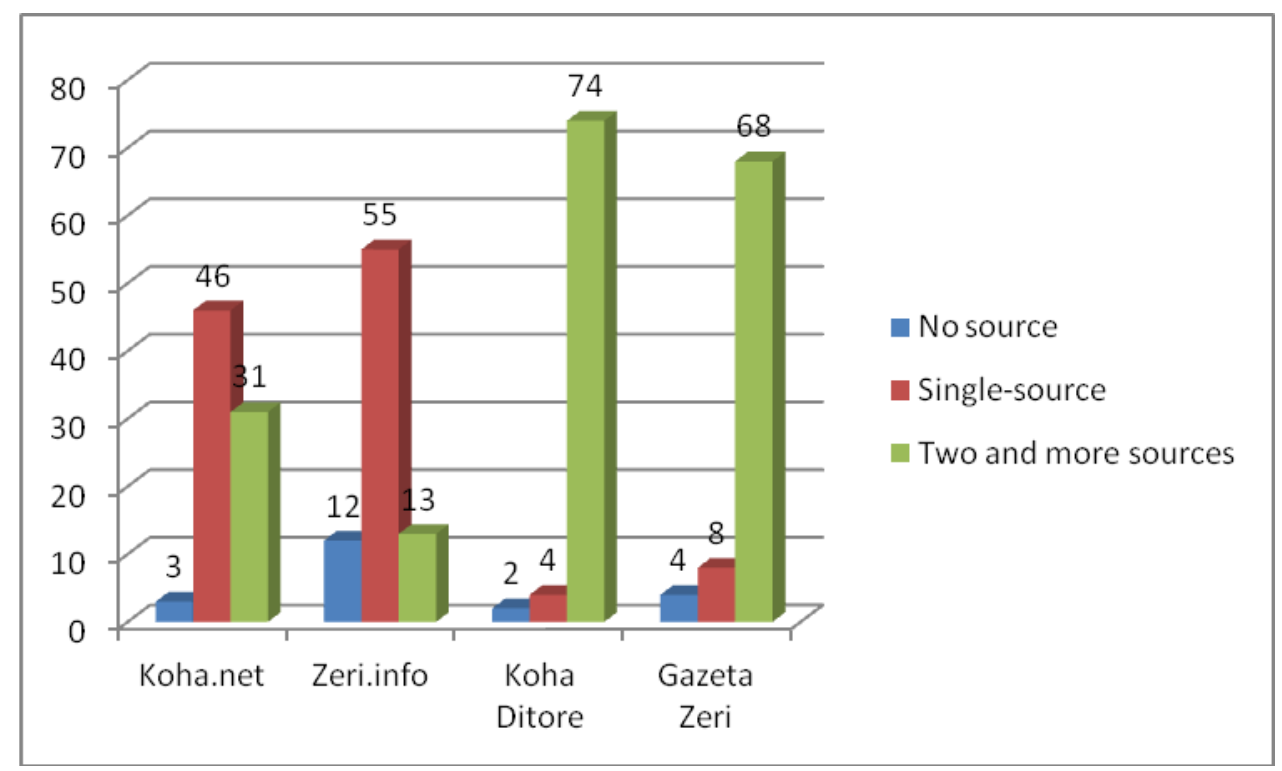

Table 3. The use of sources in texts.

Source: own processing, 2019

Single-source texts

In the koha.net, dated February 14, 2017, the latest published and noon text have the title quote. "Sherifi: Mustafa is completely dependent on the PDK" (Koha.net, 14 February 2017), the author quoted an interviewee as saying, citing problems within the ruling coalition. The title is written in eight words and is long. Only one source is cited that does not meet the balance criterion in a text despite being a quote taken from an issue and quoted on the online media. Single-source texts cannot be balanced, which is one of the basic criteria for building news.

In the text of zëri.info entitled "Maxhuni: Kosovo institutions stopped the train" (Zëri. info, 14 February 2017) it is written about an action taken by the Police in a region of Kosovo. There is only one source in the entire text: Kosovo Police Director, Maxhuni. No other source is used, despite the fact that the police director mentions the institutions and organizations that participated in this action that is not confirmed by other sources or confirmed by these organizations.

\section{Text without sources}

There are texts on the online media that come out even without any source from which address they received the information they are publishing. Thus, in the text of zëri. info entitled "Arvizu and Lu meeting with the Speaker of Parliament, Meta" (Zëri.info, 03 April 2017) writes that former US Ambassador to Tirana, Alexander Arvizu met this morning with Speaker of Parliament, Ilir Meta. It writes that Ambassador was with his successor, Donald Lu, and entered the Assembly in a meeting that lasted 30 minutes. Nowhere is it clear who is announcing this meeting. It is not indicated whether the information was received directly from the Speaker of Parliament's office, by any press release or the journalist was part of the event.

The same example is in the text of zëri.info entitled "Today's decision for Haradinaj" and it provides information that Ramush Haradinaj is expected to appear before a French court in Colmar that day. It also writes that the Former Prime Minister of Kosovo, currently the leader of the Alliance for the Future of Kosovo, was detained by French police 
on January 4 on the basis of an international arrest warrant issued by Serbia through Interpol.

Also in the text of the koha.net entitled "Investments in the riverbed eliminate floods" (Koha.net, 17 March 2017) it is stated that within 3 years, Shtimja has received about half a million Euros from various donors for the expansion and cleaning of the riverbed, Shtimjanja from the village of Caraleva to Shtime and from the rest of the village Mollopolc-Petrov to the village of Vojnoc.

It reports that the city has also built a sewage treatment plant along the riverbed as part of its environmental projects. However, sources of information are missing, blurring the fact that the data for this reporting was obtained.

\section{Convergence}

The authors of the Missouri Group book "Reporting and Writing News" emphasize the fact that in addition to text, online media should place great emphasis on video and photography. Video is becoming important for all media activities that use the website. Video is no longer the sole competence of television (Missouri Group, 2005, p.40). In fact, the advantage of video in online media compared to television is that you can watch the video on television when the television decides to broadcast it, while in the online media the reader can watch it whenever they need it and even after a while.

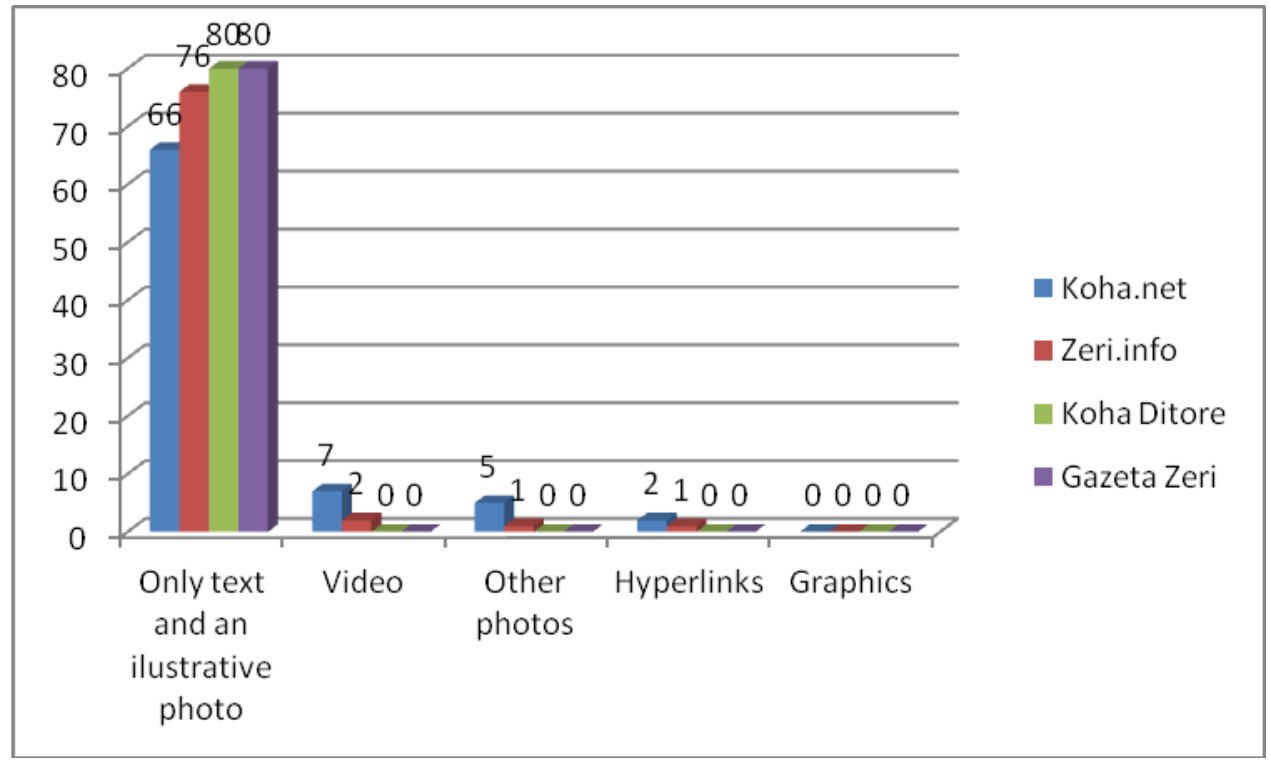

Table 4. The convergence in texts.

Source: own processing, 2019

Spanish scholars of Infotendencias Group, who are researchers from different Spanish Universities, say that "the move from 'analog journalism' to 'digital journalism' sparks a mutation in all the print, radio, television, and online media, and in their various production processes" (Infotendencias Group, 2012, p.31). However, in the Kosovo case, there is still little use of the opportunities offered by advanced technology. Most of the texts of two online media do not differ much from newspapers. They do not take advantage of the opportunity provided by the internet to produce news that have photos and videos in order to make the news easier to understand, attractive and dynamic.

Thus, in texts analyzed at koha.net, only 7 texts have videos, while the other 5 have pictures. There is a hyperlink to a text.

The same is the case with zëri.info, where 76 texts are the same as in the newspaper where only illustrative text and photography are available. Whereas, only 2 texts have video and one a photo. In another text, there is a hyperlink. Neither of these two online 
media used graphics to illustrate the story.

\section{Conclusions}

Online journalism is continuing to be transformed as compared to newspaper journalism due to the development of technology and the adaptation of texts to the audience. This study highlights exactly the change that the journalistic text has undergone in terms of structure and content. Structurally, the text on the online media has changed due to media convergence, namely the use of photos, videos and animations.

Despite these opportunities, texts in the online media in Kosovo, respectively the two online media koha.net and zëri.info, have not moved much towards using technology to further improve the way they write news online.

Based on the data of this research, which is based on the analysis of the content and textual structure of 240 news journalism texts, it turns out that the news items have not undergone a transformation from newspaper to online in terms of using internet advantages. There has been degradation in standards of journalism.

The online media use direct but also delayed and missing heads to tell the reported event. In fact, journalism standards have shifted as far as information journalism texts are concerned in online media. Most of the published texts are with only one source. Not even background is used to help the reader understand the story better. Online media do not use photos or videos. In most of the texts analyzed, the two portals publish newspaper-like texts illustrating the text with photos while missing video, additional photos and graphics.

The first hypothesis of the study is confirmed. The analysis shows that journalism from newspapers to online media is distorted also as a result of technology. Texts in online media mainly are without background, often with a single-source or maybe without any source and mostly because of the frequent publication of news.

The second hypothesis stressing that the information genre has changed substantially both in structure and content is confirmed. From the analysis of the text gathered in newspapers and online media, it can be concluded that the construction of the journalistic text has changed because texts in newspapers are quite different from those in online media, from the lead to the background.

\section{References}

AKADEMIA E SHKENCAVE DHE ARTEVE E KOSOVËS, (2018), Fjalori Enciklopedik i Kosovës, Prishtinë:Akademia e Shkencave dhe Arteve e Kosovës;

BORIÇI, H. \& NEZAJ, S., (2017), Lajmi në media, Tiranë: ISHM;

CARROLL, B, (2010), Writing for Digital Media, New York: Routledge;

DEUZE, M., \& WITSCHGE, T. (2018). Beyond journalism: Theorizing the transformation of journalism. Journalism, 19(2), 165-181;

HOXHA, A. (2017), Gara për Prishtinën rrit pakënaqësitë brenda partive, Zëri, no. 5513;

INFOTENDENCIAS GROUP (2012), Media Convergence, In E. Siapera and A. Veglis (eds.), Handbook of Global Online Journalism, West Sussex: Wiley-Blackwell;

KIM, H. ET AL., (2018), Evaluating Sampling Methods for Content Analysis of Twitter Data, SM+S, Volume: 4 issue;

KOHA (2017), Investimet në shtratin e lumit eliminojnë përmbytjet, retrieved from, https://www.koha.net/ kosove/6432/investimet-ne-shtratin-e-lumit-eliminojne-permbytjet/ , on 15.04 .2019

KOHA, SHBA-ja do transformimin e FSK-së nëpërmjet Kushtetutës, retrieved from https://www.koha.net/arberi/4016/shba-ja-do-transformimin-e-fsk-se-nepermjet-kushtetutes/ on 15.04.2019

KOHA (2017), Sherifi: Mustafa është komplet i varur nga PDK-ja, retrieved from, https://www.koha.net/arberi/331/sherifi-mustafa-eshte-komplet-i-varur-nga-pdk-ja/, on 15.04.2019 
KOHA (2017), Topalli thotë se veteranët e kanë kuptuar se ata që duhet të gjykohen në Speciale janë viktima, retrieved from https://www.koha.net/arberi/3488/topalli-thote-se-veteranet-e-kane-kuptuar-se-ata-qe-duhet-tegjykohen-ne-speciale-jane-viktima/ on 15.04.2019

KOHA DITORE (2007), Monografia e Kohës Ditore për 10 vjetorin, Prishtinë: Koha;

KOSUMI, B. (2013), Tipologji dhe zhanër, Prishtinë: Olymp;

KRASNIQI, M., Hipodromedia rikthimi i ulërimave të hipodromit, Prishtinë: PEN, 2014;

MISSOURI GROUP (2005), Raportimi dhe Shkrimi i Lajmeve, Tiranë: IDK;

NEZIRI, D. (2017) Serbia kërkon votimin dhe numërimin e votave në Kosovë, Koha Ditore, no. 7058;

PAULUSSEN, S. (2012), "Technology and the Transformation of News Work: Are Labor Conditions in (Online) Journalism Changing?" in Eugenia Siapera and Andreas Veglis (eds) The Handbook of Global Online Journalism. Malden, MA: Wiley-Blackwell;

RANDALL, D. (2000), The Universal Journalist, 2nd edition, London: Pluto Press;

RUSS-MOHL, S. (2010), Gazetaria, Tiranë: K\&B;

SCHERER, E. (2012), A na duhen gazetarët?, Tiranë: Papirus;

WARD, M. (2013), Journalism Online, Burlington: Taylor \& Francis;

Web Archivea, Retrieved from http://web.archive.org/web/19990222085830/http://koha.net/ARTA/index.htm, on 10.04.2019

Web Archiveb, Retrieved from http://web.archive.org/web/19990302022551/http://kosova.com/, on 10.04.2019

Who.is, Retrieved from https://who.is/whois/koha.net on 10.04.2019

ZËRI, (2017), Arvizu dhe Lu takim me kreun e Kuvendit, Meta, retrieved from, https://zeri.info/aktuale/137381/ arvizu-dhe-lu-takim-me-kreun-e-kuvendit-meta/, on 15.04.2019

ZËRI, (2017), Gjurqit thotë se Serbia ka prova serioze për rastin Haradinaj, retrieved from https://zeri.info/aktuale/134462/gjurqit-thote-se-serbia-ka-prova-serioze-per-rastin-haradinaj/ on 15.04.2019

ZËRI, (2017), Maxhuni: Trenin e ndalën institucionet e Kosovës, retrieved from, https://zeri.info/aktuale/130820/ maxhuni-trenin-e-ndalen-institucionet-e-kosoves/, on 15.04.2019 